\title{
Front Matter: Volume 7577
}

, "Front Matter: Volume 7577," Proc. SPIE 7577, Plasmonics in Biology and Medicine VII, 757701 (19 March 2010); doi: 10.1117/12.855212

SPIE. Event: SPIE BiOS, 2010, San Francisco, California, United States 
PROGRESS IN BIOMEDICAL OPTICS AND IMAGING

Vol. 11, No. 30

\title{
Plasmonics in Biology and Medicine VII
}

\author{
Tuan Vo-Dinh \\ Joseph R. Lakowicz \\ Editors
}

25 and 27-28 January 2010

San Francisco, California, United States

Sponsored and Published by

SPIE

Volume 7577 
The papers included in this volume were part of the technical conference cited on the cover and title page. Papers were selected and subject to review by the editors and conference program committee. Some conference presentations may not be available for publication. The papers published in these proceedings reflect the work and thoughts of the authors and are published herein as submitted. The publisher is not responsible for the validity of the information or for any outcomes resulting from reliance thereon.

Please use the following format to cite material from this book:

Author(s), "Title of Paper," in Plasmonics in Biology and Medicine VII, edited by Tuan Vo-Dinh, Joseph R. Lakowicz, Proceedings of SPIE Vol. 7577 (SPIE, Bellingham, WA, 2010) Article CID Number.

ISSN 1605-7422

ISBN 9780819479730

Published by

SPIE

P.O. Box 10, Bellingham, Washington 98227-0010 USA

Telephone +1 3606763290 (Pacific Time) · Fax +1 3606471445

SPIE.org

Copyright (C) 2010, Society of Photo-Optical Instrumentation Engineers.

Copying of material in this book for internal or personal use, or for the internal or personal use of specific clients, beyond the fair use provisions granted by the U.S. Copyright Law is authorized by SPIE subject to payment of copying fees. The Transactional Reporting Service base fee for this volume is $\$ 18.00$ per article (or portion thereof), which should be paid directly to the Copyright Clearance Center (CCC), 222 Rosewood Drive, Danvers, MA 01923. Payment may also be made electronically through CCC Online at copyright.com. Other copying for republication, resale, advertising or promotion, or any form of systematic or multiple reproduction of any material in this book is prohibited except with permission in writing from the publisher. The CCC fee code is 1605$7422 / 10 / \$ 18.00$.

Printed in the United States of America.

Publication of record for individual papers is online in the SPIE Digital Library.

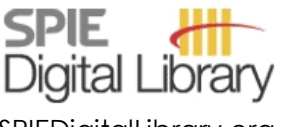

SPIEDigitalLibrary.org

Paper Numbering: Proceedings of SPIE follow an e-First publication model, with papers published first online and then in print and on CD-ROM. Papers are published as they are submitted and meet publication criteria. A unique, consistent, permanent citation identifier (CID) number is assigned to each article at the time of the first publication. Utilization of CIDs allows articles to be fully citable as soon they are published online, and connects the same identifier to all online, print, and electronic versions of the publication. SPIE uses a six-digit CID article numbering system in which:

- The first four digits correspond to the SPIE volume number.

- The last two digits indicate publication order within the volume using a Base 36 numbering system employing both numerals and letters. These two-number sets start with 00, 01, 02, 03, 04, $05,06,07,08,09,0 A, 0 B \ldots 0 Z$, followed by 10-1Z, 20-2Z, etc.

The CID number appears on each page of the manuscript. The complete citation is used on the first page, and an abbreviated version on subsequent pages. Numbers in the index correspond to the last two digits of the six-digit CID number. 


\section{Contents}

vii Conference Committee

\section{SESSION 1 SURFACE-ENHANCED RAMAN SCATTERING (SERS)}

757702 Plasmonic nanostructures for biophotonic applications [7577-01]

D. Cialla, K. K. Strelau, T. Schüler, R. Möller, Friedrich-Schiller-Univ. Jena (Germany); U. Hübner, H. Schneidewind, M. Zeisberger, R. Mattheis, W. Fritzsche, Institute of Photonic Technology Jena e.V. (Germany); J. Popp, Friedrich-Schiller Univ. Jena (Germany) and Institute of Photonic Technology Jena e.V. (Germany)

757704 Shape-dependent effect of surface-enhanced Raman scattering on gold nanostructured arrays [7577-03]

H.-Y. Lin, Institute of Biomedical Engineering, National Cheng Kung Univ. (Taiwan);

C.-H. Huang, C.-H. Chang, Institute of Electro-Optical Science and Engineering, National Cheng Kung Univ. (Taiwan); H.-L. Chui, Institute of Biomedical Engineering, National Cheng Kung Univ. (Taiwan)

\section{SESSION 2 SURFACE-ENHANCED RAMAN SCATTERING (SERS) II}

757705 Functionalized nanoparticles for measurement of biomarkers using a SERS nanochannel platform [7577-04]

M. Benford, M. Wang, J. Kameoka, Texas A\&M Univ. (United States); T. Good, Univ. of Maryland, Baltimore County (United States); G. Cote, Texas A\&M Univ. (United States)

\section{SESSION 3 SURFACE PLASMON RESONANCE METHODS AND DEVICES I}

$757708 \quad$ High sensitivity of SPR with microplasmonic structures [7577-07]

L. S. Live, J.-F. Masson, Univ. de Montréal (Canada)

$7577 \mathrm{OA}$ The detection of small organic molecules based on novel functionalized surface plasmon resonance sensors [7577-09]

R. Zheng, B. D. Cameron, Univ. of Toledo (United States)

7577 OB The circular polarization interferometer based surface plasmon biosensor [7577-10] C.-M. Jan, Y.-H. Lee, Institute of Applied Mechanics, National Taiwan Univ. (Taiwan); C.-K. Lee, Institute of Applied Mechanics, National Taiwan Univ. (Taiwan), National Taiwan Univ. (Taiwan), and Industrial Technology Research Institute (Taiwan) 
$7577 \mathrm{OH} \quad$ CMOS modulated light cameras for sensitive surface plasmon resonance imaging [7577-17]

N. S. Johnston, R. A. Light, Institute of Biophysics, Imaging and Optical Science, Univ. of Nottingham (United Kingdom); C. E. Stewart, Electromagnetic Materials Group, Univ. of Exeter (United Kingdom); M. G. Somekh, M. C. Pitter, Institute of Biophysics, Imaging and Optical Science, Univ. of Nottingham (United Kingdom)

\section{SESSION 5 METAL-ENHANCED FLUORESCENCE METHODS AND DEVICES}

7577 0J Enhanced fluorescence from metal nanoapertures: physical characterizations and biophotonic applications (Invited Paper) [7577-19]

J. Wenger, H. Aouani, D. Gérard, Institut Fresnel, CNRS, Univ. Aix-Marseille (France); S. Blair, Univ. of Utah (United States); T. W. Ebbesen, Institut de Science et d'Ingénierie Supramoléculaires, CNRS, Univ. de Strasbourg (France); H. Rigneault, Institut Fresnel, CNRS, Univ. Aix-Marseille (France)

7577 OK Metal enhanced intrinsic fluorescence of proteins and label-free bioassays [7577-20] K. Ray, H. Szmacinski, M. H. Chowdhury, J. R. Lakowicz, Ctr. for Fluorescence Spectroscopy, Univ. of Maryland School of Medicine (United States)

7577 OL Numerical and experimental study of fluorescence enhancement with silica encapsulated metallic nanoparticles [7577-21]

J. B. Zhang, J. F. Ho, Data Storage Institute (Singapore); L. Cheng, Q. Q. Teo, National Univ. of Singapore (Singapore); J. Y. Sze, B. Luk'yanchuk, Data Storage Institute (Singapore)

757700 The use of aluminum nanostructures as platforms for metal enhanced fluorescence of the intrinsic emission of biomolecules in the ultra-violet [7577-24]

M. H. Chowdhury, K. Ray, Ctr. for Fluorescence Spectroscopy, Medical Biotechnology Ctr., Univ. of Maryland School of Medicine (United States); S. K. Gray, Ctr. for Nanoscale Materials, Argonne National Lab. (United States); J. Pond, Lumerical Solutions Inc. (Canada); J. R. Lakowicz, Ctr. for Fluorescence Spectroscopy, Medical Biotechnology Ctr., Univ. of Maryland School of Medicine (United States)

\section{SESSION 6 PLASMONICS APPLICATIONS}

7577 OP Plasmon resonance gold nanoparticles for improving optical diagnostics and photothermal therapy of tumor [7577-25]

E. V. Zagainova, M. A. Sirotkina, M. V. Shirmanova, V. V. Elagin, Nizhny Novgorod State Medical Academy (Russian Federation); M. Kirillin, P. Agrba, V. A. Kamensky, Institute of Applied Physics (Russian Federation); V. A. Nadtochenko, N.N. Semenov Institute of Chemical Physics (Russian Federation)

$7577 \mathrm{OQ}$ Sub-wavelength plasmonic readout for direct linear analysis of optically tagged DNA [7577-26]

J. Varsanik, Massachusetts Institute of Technology (United States) and The Charles Stark Draper Lab., Inc. (United States); W. Teynor, J. LeBlanc, H. Clark, The Charles Stark Draper Lab., Inc. (United States); J. Krogmeier, U.S. Genomics (United States); T. Yang, K. Crozier, Harvard Univ. (United States); J. Bernstein, The Charles Stark Draper Lab., Inc. (United States) 
7577 OS Plasmon resonant gold-coated liposomes for spectrally controlled content release [7577-28]

S. J. Leung, M. C. Bobnick, M. Romanowski, The Univ. of Arizona (United States)

\section{SESSION 7 PLASMONICS PROPERTIES OF NANOSTRUCTURES I}

7577 OV Gold colloidals optical characterization by observing their scattering polarization [7577-31] B. Al-Qadi, T. Saiki, Keio Univ. (Japan)

7577 0X Extraction of complex refractive index dispersion from SPR data [7577-33]

M. Nakkach, Lab. Charles Fabry de l'Institut d'Optique, CNRS, Univ. Paris-Sud (France) and Lab. de Spectroscopie Atomique Moléculaire et Applications (Tunisia); J. Moreau, M. Canva, Lab. Charles Fabry de I'Institut d'Optique, CNRS, Univ. Paris-Sud (France

\section{SESSION 8 PLASMONICS PROPERTIES OF NANOSTRUCTURES II}

$75770 Z$ Experimental and numerical analysis of extraordinary optical transmission through nano-hole arrays in a thick metal film [7577-35]

M. Najiminaini, F. Vasefi, Simon Fraser Univ. (Canada) and Lawson Health Research Institute (Canada); C. K. Landrock, B. Kaminska, Simon Fraser Univ. (Canada); J. J.-L. Carson, Lawson Health Research Institute (Canada) and Univ. of Western Ontario (Canada)

757712 Biodegradable near-infrared plasmonic nanoclusters for biomedical applications [7577-39] J. O. Tam, J. M. Tam, A. Murthy, D. Ingram, L. L. Ma, K. Travis, K. P. Johnston, The Univ. of Texas at Austin (United States); K. Sokolov, The Univ. of Texas at Austin (United States) and MD Anderson Cancer Ctr., The Univ. of Texas at Austin (United States)

\section{POSTER SESSION}

757714 SERS+MEF of the anti-tumoral drug emodin adsorbed on silver nanoparticles [7577-41] P. Sevilla, Instituto de Estructura de la Materia, CSIC (Spain) and Univ. Complutense de Madrid (Spain); R. De Llanos, C. Domingo, S. Sánchez-Cortés, J. V. García-Ramos, Instituto de Estructura de la Materia, CSIC (Spain)

757715 Synthesis, optical and microscopical characterization of albumin/porous silica/gold nanorods [7577-42]

F. Ratto, Istituto di Fisica Applicata Nello Carrara, CNR (Italy); S. Centi, Univ. degli Studi di Firenze (Italy); P. Matteini, F. Rossi, R. Pini, Istituto di Fisica Applicata Nello Carrara, CNR (Italy)

757716 Stability of cetrimonium and silica modified gold nanorods/polyvinyl alcohol nano-composites upon near infrared laser excitation [7577-43] F. Ratto, P. Matteini, Istituto di Fisica Applicata Nello Carrara, CNR (Italy); S. Centi, Univ. degli Studi di Firenze (Italy); F. Rossi, R. Pini, Istituto di Fisica Applicata Nello Carrara, CNR (Italy)

757718 The plasmonic Raman sensor using periodic nanofocusing arrays [7577-45] K. Yamaguchi, Toyohashi Univ. of Technology (Japan); M. Fujii, Toba National College of Maritime Technology (Japan); M. L. Kurth, S. J. Goodman, Queensland Univ. of Technology (Australia); D. K. Gramotnev, Nanophotonics Pty Ltd. (Australia); P. Fredericks, Queensland Univ. of Technology (Australia); M. Fukuda, Toyohashi Univ. of Technology (Japan) 
757719 Momentum mismatch for improved plasmon enhanced total internal reflection fluorescence imaging [7577-47]

Y. Oh, K. Kim, K. Ma, E. Sim, D. Kim, Yonsei Univ. (Korea, Republic of)

Author Index 


\title{
Conference Committee
}

\author{
Symposium Chairs \\ James G. Fujimoto, Massachusetts Institute of Technology \\ (United States) \\ R. Rox Anderson, Wellman Center for Photomedicine, Massachusetts \\ General Hospital (United States) and Harvard School of Medicine \\ (United States)
}

Program Track Chairs

Paras N. Prasad, University of Buffalo (United States)

Dan. N. Nicolau, The University of Liverpool (United Kingdom)

Conference Chairs

Tuan Vo-Dinh, Duke University (United States)

Joseph R. Lakowicz, University of Maryland School of Medicine

(United States)

\section{Session Chairs}

1 Surface-Enhanced Raman Scattering (SERS)

Tuan Vo-Dinh, Duke University (United States)

Anuj Dhawan, Duke University (United States)

2 Surface-Enhanced Raman Scattering (SERS) II

Tuan Vo-Dinh, Duke University (United States)

Anuj Dhawan, Duke University (United States)

3 Surface Plasmon Resonance Methods and Devices I

Michael Canva, Laboratoire Charles Fabry de l'Institu† d'Optique (France)

$4 \quad$ Surface Plasmon Resonance Methods and Devices II

Michael Canva, Laboratoire Charles Fabry de l'Institut d'Optique (France)

5 Metal-Enhanced Fluorescence Methods and Devices

Mustafa H. Chowdhury, University of Maryland School of Medicine (United States) 
6 Plasmonics Applications

Mustafa H. Chowdhury, University of Maryland School of Medicine (United States)

7 Plasmonics Properties of Nanostructures I

Jean-Francois Masson, Université de Montréal (Canada)

8 Plasmonics Properties of Nanostructures II

Steve Blair, The University of Utah (United States) 